\title{
A Catábase de Orfeu e a queda de Lúcifer: a identidade do poeta como um herói caído
}

\author{
Orpheus' katabasis and the fall of Lucifer: the poet's identity as \\ a fallen hero
}

Fábio Gerônimo Mota Diniz

UNESP-Araraquara

fabiogeronimo@gmail.com

RESUMO: A partir de uma comparação entre as figuras do herói mítico grego Orfeu e do anjo caído da mitologia judaico-cristã Lúcifer, pretende-se apresentar uma faceta possível da figura do poeta que coincide com a do anjocaído. A ideia é propor um tópos referencial simbólico a partir do qual se compreenderá o artista, especialmente o poeta, como um herói que, rebelado contra certa instância de poder, sofre uma queda ocasionada por um erro inescapável. Nessa queda se revela a angústia humana fundamental, do reconhecimento da sua própria existência e sua fragilidade diante do pecado original, que operam como motores fundamentais do seu fazer poético, derivado dessa crise instaurada na identidade do eu-criador. Assim, partindo dessa nossa análise dos dois personagens arquetípicos e das observações do filósofo dinamarquês Søren Kierkegaard sobre a angústia existencial do ser humano diante do pecado original, faremos a proposta de uma percepção do herói/anjo caído como um dos possíveis arquétipos identitários desse poeta angustiado.

Palavras-chave: Catábase. Orfeu. Lúcifer. Poeta. Søren Kierkegaard. Arquétipo.

ABSTRACT: Starting from a comparison between Greek mythical hero Orpheus and Judeo-Christian mythology fallen angel Lucifer, we aim to present a conceivable facet of the poet's figure which coincides with the fallen angel's figure. The idea is to propose a referential symbolic tópos from which we will understand the artist, especially the poet, as a hero who, rebelled against a certain power sphere, falls due to an inescapable mistake. In this fall, human fundamental angst is revealed, that of recognizing its own existence and fragility in the face of the original sin, which operates as poetic creation's

Revista Texto Poético | ISSN: 1808-5385 | Vol. 18 (10 sem-2015) - p. 209 
fundamental engine, derived from this crisis in the creator's identity. Thus, based on the analyses of these two archetypical characters, as well as Danish philosopher Søren Kierkegaard's remarks on human's existential angst towards the original sin, we shall propound the perception of the hero/fallen angel as one of the anguished poet's possible archetypes.

Keywords: Katabasis. Orpheus. Lucifer. Poet. Søren Kierkegaard. Archetype.

Orfeu não é apenas o personagem mítico da antiguidade clássica que representa o estatuto mágico e místico da arte poética, mas, sobretudo, é o protótipo do grande poeta, o Poeta com "P" maiúsculo - no caso, o aedo, uma figura da antiguidade que reunia em si aspectos singulares que convergiam o aspecto performático do cantor e o aspecto religioso. $\mathrm{E}$

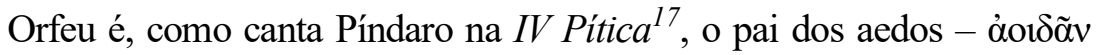
$\pi \alpha \tau \eta ́ \rho$ / aoidān patér ${ }^{18}$-, ou seja, o primeiro dos poetas da mitologia.

O nome do herói grego, de origem incerta, aponta para essa relação com a obscuridade, com esse papel misterioso e ritualístico que lhe é atribuído. Segundo Chantraine (1999, p. 829), o radical orph-, que aparece também na palavra orphanós, "órfão", é o mesmo de órphne, "escuridão", e ocorre em todos seus derivados. Porém, antes de sua descida ao Hades, encontramos nos mitos relacionados ao herói uma íntima relação entre ele e Apolo, deus solar e, portanto, ligado à luz, e que em algumas versões é considerado seu pai. Durante toda a viagem dos argonautas narrada no poema épico alexandrino Argonáutica, de Apolônio de Rodes - uma das fontes antigas mais importantes para a participação de Orfeu na viagem -, evidencia-se essa relação entre o poder do canto de Orfeu como derivado de sua relação com Apolo. Já a

${ }^{17}$ A Pítica $I V$ se destaca também por ser uma das primeiras referências à viagem dos argonautas, incluindo Orfeu como membro da tripulação.

${ }^{18}$ Para facilitar o acesso às análises de termos específicos, todas as palavras gregas e hebraicas discutidas no texto estão transliteradas para caracteres latinos, com os sinais diacríticos correspondentes.

Revista Texto Poético | ISSN: 1808-5385 | Vol. 18 (10 sem-2015) - p. 210 
partir de sua descida ao Hades, o herói assume uma relação mais íntima com outra divindade, Dioniso, o que talvez o localize exatamente nesse mundo da escuridão ao qual seu nome remete ${ }^{19}$.

O herói é, ainda, fundador de uma ordem religiosa e mística, o Orfismo, um dos diversos cultos de mistério que, na Antiguidade Clássica, foram fundamentais tanto do ponto de vista religioso quanto do ponto de vista filosófico. O Orfismo dialoga e influencia não apenas o pensamento de várias correntes filosóficas, como a de Platão e seus seguidores, mas vários elementos da cultura grega - e ocidental posterior, a ponto de ser difícil desvencilhar o universo místico-religioso do poético.

Porém Orfeu, em seu principal mito, destaca-se por ser uma figura que vivencia a queda, a chamada catábase. Ao descer ao Hades em busca de sua amada Eurídice, o herói se perde e acaba sendo morto e despedaçado. $\mathrm{O}$ desespero de Orfeu e a sua destruição são motivo de vasta poesia da antiguidade até a contemporaneidade, tornando-o referencial para diversos tópoi literários, que investem tanto sobre a relação do poeta com sua musa, como sobre essa catábase do herói. Como observa Rosado Fernandes:

Embora não possa considerar-se o termo grego katábasis, «acção de descer, descida», como expressão de técnica literária, a verdade é que as «descidas», subentende-se aos infernos, eram um tópos da literatura antiga, que dai transitou para as literaturas modernas. O seu contrário, anábasis, «subida», foi consagrado pela obra de Xenofonte na «Retirada dos Dez Mil», mas nunca assumiu o carácter infinitizante da "catábase», que significa toda e qualquer descida às regiões subterrâneas, ao passo que «anábase» significa tão-somente a subida das tropas de mercenários gregos pelas montanhas da

${ }^{19}$ Acerca da relação entre Orfeu e essas figuras divinas, bem como outros temas relativos ao mito argonáutico do herói, conferir DINIZ, 2014, passim.

Revista Texto Poético | ISSN: 1808-5385 | Vol. 18 (10 sem-2015) - p. 211 
Arménia depois da derrota infligida a Ciro pelas tropas de seu irmão Antaxerxes. (FERNANDES, 1993, p. 347)

Essa "infinitização" que a catábase permite é fundamental no reconhecimento dos traços órficos na figura tradicional do Poeta, e aqui estamos lidando com o criador como uma instância, como um ser que possui uma identidade fruto de uma tradição e construída em relação a esse referencial toponímico. Toponímico pois, em suma, Orfeu como arquétipo poético seria o nome do lugar, do ponto de onde parte - e pelo qual caminha - toda uma percepção não apenas de poesia, mas de um Poeta, ou seja, da figura responsável pelo ato criador poético. Se considerarmos a poesia a partir de sua origem místico-religiosa, Orfeu é o centro difusor, como aoidān patếr, de toda arte criadora, e compreender sua catábase permitiria, numa visão arquetipológica, compreender a identidade desse eu-criador que tem em Orfeu sua origem.

Orfeu é símbolo do misticismo e, sobretudo, da poesia, uma figura que interessa ainda justamente por ser, ao mesmo tempo, criador e criatura, Poeta e personagem da Poesia. De tal modo, divergimos de Rosado, e utilizaremos a catábase como uma expressão de técnica literária, na medida em que nos permitirá compreender Orfeu toponimicamente. A sua catábase, como tópos, se relaciona intimamente com a sua identidade de Poeta e, como o reflexo dessa identidade na tradição que dele deriva, pode servir de motivo fundamental no estabelecimento de um referencial "órfico" de Poeta ${ }^{20}$.

${ }^{20}$ A proposta, em suma, é que há ao menos duas possibilidades de identificação de um arquétipo do Poeta: a perspectiva órfica e a não-órfica. A perspectiva não-órfica se situa numa comparação entre Orfeu e uma contraparte que possua elementos suficientes para constituir-se como outro topônimo e, apesar de ser uma reflexão que já desenvolvemos, é algo que não será analisado neste texto, tanto por desviar do recorte escolhido quanto por falta de espaço.

Revista Texto Poético | ISSN: 1808-5385 | Vol. 18 (10 sem-2015) - p. 212 
Portanto, para investigar a validade da catábase como tópos, elegemos outro "herói caído" como parâmetro de comparação, para construir uma proposta de um tópos do poeta órfico. Nosso escolhido foi o personagem tradicionalmente conhecido como Lúcifer, que em si traz elementos muito mais complexos em sua delimitação, e que em sua pluralidade traz pontos de contato e contraste significativos com Orfeu.

Um contraste interessante se dá com a suposta origem do nome de Orfeu: o nome Lúcifer vem do latim, lux fero, "o portador da luz", e como observa Vailatti (2014, p. 116), foi a opção de Jerônimo ao traduzir dessa forma o famoso trecho bíblico do livro de Isaías, 14, 12, do hebraico הילה

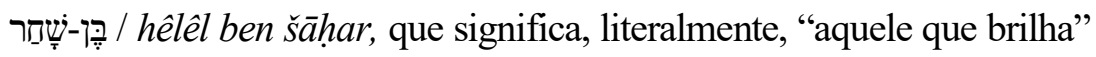
ou que "traz a luz", que tornou reconhecido o nome Lúcifer ${ }^{21}$. O ser chamado por esse nome foi associado à figura amplamente conhecida por Satã na cultura cristã, a ponto de Lúcifer deixar de ser um epíteto para se tornar outro nome do mesmo Satã, mas essa relação é posterior ao trecho em questão, que se referiria a um ambicioso rei da Babilônia, e por isso seria uma expressão metafórica que, como observa Fekkes, se estabelece ao menos a partir de Orígenes de Alexandria (Séc. II):

To begin with, the spiritual interpretation of Isa. 14.12 with reference to a fall of Satan is only first attested certainly with Origen. While such an exegesis is also contained in 2 En. 29.3-5 and Adam and Eve 12-16, neither of these works can be positively dated before 100 CE. To be sure, early Jewish interpretation and reapplication of Isaiah 14 can be found in many places, but is never referred to Satan. Rabbinic testimony from at least the time of Johanan $b$.

${ }^{21}$ No caso, Jerônimo traduz o substantivo hebraico hêlêl, "brilhante", por uma forma latina, lucifer, que deriva de lux, lucis, "luz" e fero, de ferre, "trazer", ou seja, "aquele que traz a luz".

Revista Texto Poético | ISSN: 1808-5385 | Vol. 18 (10 sem-2015) - p. 213 
Zakkai (t c. $80 \mathrm{CE}$ ) interprets the passage uniformly of Nebuchadnezzar ${ }^{22}$.

Kelly (2008, p. 227-246) comenta que a visão de Orígenes, junto a outras posteriores, acabou por sacramentar a passagem como referente à Lúcifer e, assim, desenvolver uma "Nova Biografia de Satã", que converge figuras díspares como a serpente do Éden e o Dragão derrotado pelo arcanjo Miguel no livro do Apocalipse de São João. Essa será a nossa referência para a análise a ser desenvolvida no presente trabalho que parte, de tal modo, de uma comparação entre a iconografia da queda de Orfeu com a desse suposto anjo caído da mitologia judaico-cristã, Lúcifer. Vailatti (2014, p.115) observa que mesmo na Vulgata de São Jerônimo a forma lucifer nunca é utilizada para se referir a anjos, mas sempre a astros celestes.

De tal modo, é importante salientar que trabalhamos essas personagens arquetipicamente e, por conseguinte, a relação que pretendemos construir é muito mais iconográfica e alegórica, pela pluralidade dos mitos relativos às duas figuras. Assim, não enxergamos como empecilho para a proposta a dificuldade de identificar com exatidão uma figura unitária sob o nome de Lúcifer, posto que, como trabalhamos com um sistema de imagens arquetípicas que constituem um imaginário da queda, seguimos justamente essa "Nova Biografia" que surge pela leitura dos seus vários intérpretes - Orígenes de Alexandria,

${ }^{22}$ Para começar, a interpretação espiritual de $I s a$. 14, 12 com referência a uma queda de Satã é apenas atestada com certeza com Orígenes. Enquanto tal exegese também se encontra em 2 En. 29, 3-5 e Adão e Eva 12-16, nenhum desses trabalhos pode ser positivamente datado antes de 100 d.C. Com certeza, a antiga interpretação judaica e reaplicação de Isaías 14 pode ser achada em vários lugares, mas nunca está se referindo a Satã. Um testemunho rabínico de ao menos à época de Johanan b. Zakkai (c.80 d.C.) interpreta a passagem uniformemente como referente a Nabucodonosor. (FEKKES, 1994, p. 187, tradução nossa).

Revista Texto Poético | ISSN: 1808-5385 | Vol. 18 (10 sem-2015) - p. 214 
Tertuliano, São Jerônimo, dentre outros -, ou seja, a visão ortodoxa, mas popular, de Lúcifer como sendo um anjo caído, e de tal modo o protagonista da passagem em Isaías 14, mesmo que essa não corresponda diretamente a uma análise filológica do termo in loco.

Para tanto, o texto divide-se em duas partes: a primeira compara as duas figuras, partindo de excerto de um artigo do professor Antônio Donizeti Pires (2013), e fundamenta-se principalmente nas narrativas míticas sobre o herói grego, nessa passagem bíblica, do livro de Isaías; já a segunda parte debate o "pecado" órfico e luciferiano, e as consequências desse erro para a poesia, a partir das observações do filósofo dinamarquês Søren Kierkegaard sobre a angústia existencial do ser humano diante do pecado original - que, de certo modo, também traz um importante traço adâmico a ser considerado. Objetivamos, nesse contexto, estabelecer uma relação entre o pecado do herói caído, a angústia decorrente desse pecado e o fazer poético, entendendo Orfeu como figura prototípica do Poeta, e sua biografia mítica como símbolo do fazer artístico.

\section{A queda do herói}

Pires (2013, p. 69-70) observa que o mito de Orfeu seria constituído de quatro mitemas: (a) a viagem ao lado dos argonautas, (b) o casamento com Eurídice, (c) a catábase e (d) a morte por esquartejamento. $\mathrm{O}$ autor destaca, ainda, que o mito órfico se dividiria em três porções:

Se o primeiro mitema é vincadamente épico, tendo nos legado epopeias e poemas épicos como a anônima Argonáuticas órficas ou a Argonáutica de Apolônio de Rodes ou a de Valério Flaco, os outros três são por 
natureza líricos e dramáticos: assim o doloroso e fatal amor de Orfeu e Eurídice, a frustrada descida do Poeta ao Inferno $e$ a sua posterior morte violenta, por esquartejamento, fizeram brotar, principalmente desde Ovídio e Virgílio, uma pletora de poemas líricos, poemas dramáticos, óperas, tragédias, tragicomédias e filmes, além de pinturas, esculturas, mosaicos, contos, romances e histórias em quadrinhos (PIRES, 2013, p. 70).

O paralelo da vida de Orfeu com o desenvolvimento da arte poética em seu modelo clássico - ou seja, a divisão em épico, lírico e trágico -, é uma divisão muito adequada tendo em vista a figura do herói como protótipo do Poeta. Além disso, parece-nos que Pires abre a possibilidade de uma leitura na qual cada estágio do mito estaria relacionado diretamente a um dos gêneros, isto é, (a) a viagem ao lado dos argonautas corresponderia ao gênero épico, (b) o casamento com Eurídice ao lírico e (c) a catábase e (d) a morte por esquartejamento ao trágico.

Mais importante para nós, porém, é a divisão do mito feita pelo autor, que considera o casamento, a catábase e a morte como mitemas distintos. Em nossa perspectiva, que debateremos a seguir, esses mitemas representam, na verdade, um único "supermitema", que, ao lado da viagem, configuram o mesmo tópos: a queda do herói Orfeu.

A queda como tópos refere-se a todo personagem mítico que cai de uma situação de prestígio, plenitude e heroísmo para uma situação de desprestígio, angústia e penitência. Nesse sentido, maior símbolo da queda no contexto judaico-cristão ocidental é a figura de Lúcifer, que de entidade participante do universo celestial e divino é arremessado, por conta de seu orgulho, para o mais profundo inferno.

A queda de Lúcifer coincide com a de Orfeu em alguns pontos: em primeiro lugar, ambas as figuras são seres ligados ao universo da luz - 
no caso de Lúcifer, como salientamos anteriormente, a lux encontra-se no seu próprio nome - e a uma divindade solar - Deus/Javé e Apolo, que caem em direção ao mundo escuro e tenebroso dos infernos, da caverna subterrânea. Em segundo lugar, ambos caem por ações que, a priori, definiremos como "individualistas": Orfeu casa-se com a ninfa Eurídice, e Lúcifer, por soberba, rebela-se contra Deus. Mesmo que o ato de Orfeu não seja em si um erro, como no caso de Lúcifer, o herói grego é motivado pelo desejo, como o anjo ${ }^{23}$ que deseja ser semelhante ao próprio Deus.

A fonte mais famosa acerca dessa queda talvez seja a mais controversa delas: o livro bíblico do Profeta Isaías, 14:12-15. Foi a tradução de São Jerônimo um dos textos que tornaram popular a relação entre o personagem mencionado no trecho e Satã, ao chamálo pelo nome de Lúcifer:

12 quomodo cecidisti de caelo lucifer qui mane oriebaris corruisti in terram qui vulnerabas gentes ${ }^{13}$ qui dicebas in corde tuo in caelum conscendam super astra Dei exaltabo solium meum sedebo in monte testamenti in lateribus aquilonis ${ }^{14}$ ascendam super altitudinem nubium ero similis Altissimo ${ }^{15}$ verumtamen ad infernum detraheris in profundum $\operatorname{laci}^{24}$.

${ }^{23}$ Retomando os apontamentos da introdução, é importante reafirmar a nossa interpretação de hêlêl, a "estrela da manhã", como o lux fero, Lúcifer, pois interessanos mais a alegoria construída a partir da imagem da queda do rei da Babilônia como sendo a queda de um ser brilhante, o anjo caído. Interessa-nos, de tal modo, muito mais o desejo e a ambição que conduzem à queda que a natureza do ser apresentado na passagem - e, portanto, continuaremos a chamar o astro de anjo, e o anjo de Lúcifer em referência a essa tradição alegórica.

${ }^{24}{ }^{12}$ Como caíste do céu, Lúcifer, nascido da manhã! Tu, que na terra despencaste, que castigava nações, ${ }^{13}$ que dizias em teu coração: "subirei ao céu acima dos astros de Deus, exaltarei meu trono e me sentarei no monte do testamento ao lado do norte,

Revista Texto Poético | ISSN: 1808-5385 | Vol. 18 (1o sem-2015) - p. 217 
Na tradução de São Jerônimo se evidencia ainda, como na fonte hebraica $^{25}$, a relação entre esse ser que carrega a luz e a própria estrela da manhã em mane oriebaris, que remete inevitavelmente ao próprio alvorecer. Oriebaris é uma forma do verbo orior, "ascender", "subir", "nascer", e é uma palavra que se encontra na raiz de orientis, "oriente", a própria direção do nascer do sol $^{26}-\mathrm{em}$ oposição ao poente, occidentis, "ocidente", derivado do verbo occido, "cair", "descer", "perecer". Ou seja, de certo modo parece ser impossível dissociar a figura descrita em Isaías e o movimento do astro solar e, posto que se trata daquele que descende do próprio nascer do sol, podemos considerá-lo como sendo, talvez, o próprio sol. E, como observa Forsyth, essa associação, que permanece na tradução de São Jerônimo, está não apenas na versão grega como também no próprio texto hebraico:

Šahar, in various Hebrew contexts, preserves some of its old mythological meaning as a feminine dawn goddess, and the original of this feminine dawn may well have been the Indo-European goddess Usas, the Heōs of Homer and

${ }^{14}$ ascenderei à altura das nuvens e serei semelhante ao Altíssimo". ${ }^{15}$ Contudo, ao inferno serás levado, ao profundo abismo. (JEROME, s/d, tradução nossa).

${ }^{25}$ Como resgatamos alguns poucos elementos da versão hebraica do trecho bíblico mesmo não tendo domínio da língua hebraica, apresentamos aqui como referência suplementar a tradução direta do hebraico de Carlos Augusto Vailatti, a partir de texto da tradição massorética da Biblia Hebraica Stuttgartensia (VAILATTI, 2014, p. 117): "12 Como caíste dos céus, ó brilhante, filho da Alvorada! Foste cortado para a terra o que enfraquecia os povos! ${ }^{13} \mathrm{E}$ tu dizias em teu coração: "subirei aos céus, acima das estrelas de El exaltarei o meu trono e me assentarei no monte da assembleia, ao lado do norte; ${ }^{14}$ Subirei acima das nuvens; serei como o Altíssimo". ${ }^{15}$ Contudo, ao she'ôl serás rebaixado, às partes extremas da cova".

${ }^{26}$ Para evidenciar essa simbologia, optamos, em nossa tradução, por manter a ideia de "nascimento" ao invés de seguir a tradicional versão por "filho da manhã/aurora".

Revista Texto Poético | ISSN: 1808-5385 | Vol. 18 (10 sem-2015) - p. 218 
Hesiod, perhaps blended now with the Semitic Ishtar. Her son, Hêlēl, may possibly be the sun itself, and indeed Šahar may mean the rising sun, according to an older school of thought, or Hêlel may be an allusion to the planet Venus, as most modern commentators on the passage believe. Whether or not the composer of the Isaiah passage made this explicit identification, the Greek translators do the Septuagint certainly did, since their translation of Hêlêl ben šăhar as Heōsphoros ho prōi anatellōn clearly combines the astronomical identification with Hesiod's Heōsphoros, son of Heōs, the dawn-bringer, Venus. The Greek was in turn rendered by the Latin vulgate as Lucifer, qui mande oriebaris, an the name has stuck to the rebel ever since ${ }^{27}$.

E, claro, como um astro que ascende e traz a luz de um novo dia, a queda desse lucifer é extremamente simbólica, especialmente porque o caído visa a uma ascensão ainda maior, que ultrapasse os próprios astros. A ascensão aqui não é apenas o movimento do astro, mas um desejo, e é esse desejo de ascensão, de assemelhar-se ao Altíssimo, que acaba conduzindo o suposto anjo à queda em direção ao שאול / She'ôl, que seria o "abismo", um local análogo ao Hades grego - e, por conta disso, o termo é tradicionalmente traduzido nas

${ }^{27} \check{S} a h a r$, em vários contextos hebreus, preserva alguns de seus velhos sentidos mitológicos como o de uma deusa feminina da aurora, e o original dessa aurora feminina pode ter sido a deusa Indo-europeia Usas, a Heōs de Homero e Hesíodo, talvez misturada agora com a semítica Ishtar. Seu filho, Hêlèl, pode ser possivelmente o próprio sol, e de fato Šahar pode significar o sol nascente, de acordo com uma antiga escola de pensamento, ou Hêlēl pode ser uma alusão ao planeta Vênus, como a maioria dos comentadores modernos da passagem acreditam. Tenha ou não o compositor da passagem de Isaías tornado essa identificação explícita, os tradutores gregos da Septuaginta certamente o fizeram, já que sua tradução de Hêlêl ben šăhar como Heōsphoros ho prōi anatellōn claramente combina a identificação astronômica com o Heōsphoros de Hesíodo, filho de Heōs, o portador da aurora, Vênus. O grego estava por sua vez rendido pela vulgata latina como Lucifer, qui mande oriebaris, e o nome se prendeu ao rebelde desde então. (FORSYTH, 1989, p. 135-136, tradução nossa).

Revista Texto Poético | ISSN: 1808-5385 | Vol. 18 (10 sem-2015) - p. 219 
versões gregas dos textos bíblicos por Ađ§ฺ / Hádēs. O erro de Orfeu ocorre depois da morte de Eurídice: ao descer ao Hades e buscá-la, Orfeu sobe em direção ao mundo dos vivos e, desobedecendo às orientações dadas a ele pelas divindades, olha para trás para contemplar a sua amada, o que a impede definitivamente de retornar à vida.

Nos dois mitos é possível perceber a presença de pelo menos um erro fundamental: a desobediência à divindade - Deus/Hades e Perséfone -, motivada por um desejo - Eurídice/tornar-se um deus - que leva à queda real. As ações ocorrem seguindo uma "coreografia", pois, para cair, faz-se necessária a ascensão do herói: assim como Lúcifer quer estabelecer-se "no ponto mais elevado de Zafon" e é arremessado ao She'ôl, Orfeu sobe ao mundo dos mortos e, ao desejar ver o rosto de sua amada, é arremessado à perdição.

Fica claro que nossa perspectiva de análise diverge do que é comumente debatido sobre a queda de Orfeu pois, em geral, o movimento de decadência é observado como sendo apenas a sua catábase. Nossa observação do mito, porém, demonstra que é possível entender a descida ao Hades, uma ação motivada pela morte da amada, não como uma queda em si, mas como consequência do erro e, por isso, estaria diretamente ligada ao desejo, que aconteceria como sequência a uma ascensão ou tentativa de ascensão.

De tal modo, os mitemas órficos do (b) casamento, (c) catábase e (d) morte se configurariam em apenas um mitema, o da (b) queda, que se desenvolve em duas circunstâncias: a ação consequente - ou seja, no caso de ambos, (i) o desejo e (ii) o erro -, e o movimento de (i') ascensão e (ii') queda.

O desenvolvimento do mitema da queda, de tal modo, conduz a uma consequência final também similar. No mito de Orfeu, 
observamos o esquartejamento do protagonista, cuja cabeça é vista boiando nas águas do rio Hebro e é recolhida ainda a cantar - uma imagem que pode ser observada como uma simbologia da permanência da fama e do poder de Orfeu, da sua arte, mesmo depois de sua morte. Do mesmo modo, em Isaías, logo após o trecho destacado, é dito que Lúcifer pode ser visto após a queda, e que aqueles "que te veem fitam os olhos em ti e te observam com toda atenção, indagando: 'Porventura é este homem que fazia tremer a terra inteira, que abalava reinos?"'. Ambos os mitos se encerram com um momento em que é possível observar o herói caído. Isso é muito significativo, tendo em vista que não apenas ambos são seres diretamente ligados à luz em sua origem, mas ainda pelo fato de ambos terem descido/caído para um abismo, um buraco, o universo das profundezas e da escuridão. A oposição luz/escuridão se ressignifica após a queda pela possibilidade da revelação do escondido, do caído, e pelo reconhecimento de seu poder mesmo depois da queda, posto que, nos dois casos, a fama do herói permanece.

Entretanto, tendo em vista que o mitema da queda se configura como parte de um mito maior, o do herói caído, como se dá a relação entre as circunstâncias da queda e o outro mitema, da viagem dos argonautas? Apesar de haver uma coincidência considerável entre Lúcifer e Orfeu, é difícil identificar com a mesma profundidade essa relação no outro mitema visto que, antes de cair, Lúcifer era apenas mais um anjo, e é justamente essa indistinção em relação a seu grupo que o caracterizava. Pode-se considerar que Orfeu, dentro de um grupo de heróis como ele - os argonautas -, seria também uma figura parcialmente indistinta, visto que, mesmo tendo habilidades e características específicas, ele se encontra no mesmo nível de todos 
os companheiros, todos heróis de - ou em busca de - fama e renome. Há ainda o fato de, na relação que Pires estabelece entre as passagens da vida de Orfeu e os gêneros poéticos, o mitema argonáutico representar a parcela épica da poesia, o que condiz com um universo no qual prevalece a coletividade. Assim, o mitema da queda se oporia, necessariamente, ao universo tradicional do heroísmo.

Mas, ainda assim, inferir que a relação entre os heróis grego e judaico-cristão se configura de uma mesma forma no mitema inicial poderia conduzir a uma interpretação enviesada do mito de Lúcifer, visto que nos falta informação para sustentar uma comparação mais profunda. De qualquer forma, com as informações que colhemos, podemos construir ao menos um sistema representativo para os mitemas ligados a Orfeu, tomando-se Lúcifer por parâmetro de comparação.

O esquema apresentado a seguir é constituído por duas narrativas mítico-alegóricas que trazem em si o significado didático do tópos. O tópos se desenvolve a partir de mitos, e nenhum mito existe sem narrativa. A maior parte dos mitos tem alguma relação, em sua origem, com o universo da oralidade e, de algum modo, a apresentação dessas narrativas conduz a uma função didática, ou seja, o conhecimento do mito leva a um aprendizado. Pela sua natureza, portanto, chamaremos cada uma dessas narrativas de mythos, pois não apenas são fundamentadas em mitos, como se desenvolvem narrativamente e, de modo análogo à palavra grega que dá origem ao termo, são discursos, "falas" que produzem conhecimento na audiência.

Não queremos, com isso, afirmar que o mito de Orfeu seja em si didático, como o de Lúcifer. É evidente a presença do ensinamento moral na descrição que Isaías traz do mito luciferiano, mas, no caso 
de Orfeu, seu erro é muito mais o motor da queda que levará, ao fim, à constituição e seu legado. Porém, para nossa experiência de comparação, apresentaremos o mito órfico como símbolo das consequências de um erro, a desobediência, e de tal modo, fábula da compreensão desse erro como origem de uma angústia existencial, a ser tratada na segunda parte do texto.

Por ora apresentaremos, no esquema abaixo, o desenvolvimento dos dois mythos dentro desses dois mitemas que fazem parte desse tópos:

\begin{tabular}{|c|c|c|c|c|c|c|}
\hline \multicolumn{7}{|c|}{ O tópos do herói caído } \\
\hline & \multirow[b]{4}{*}{ Heróis } & Mitema a & \multirow{2}{*}{\multicolumn{4}{|c|}{$\begin{array}{c}\text { Mitema b } \\
\text { Queda }\end{array}$}} \\
\hline & & \multirow[b]{3}{*}{ Heroísmo } & & & & \\
\hline & & & \multicolumn{2}{|c|}{ Ação } & \multicolumn{2}{|c|}{ Movimento } \\
\hline & & & (i) o desejo & $\begin{array}{l}\text { (ii) } 0 \\
\text { erro }\end{array}$ & $\begin{array}{c}\text { (i') } \\
\text { ascensão }\end{array}$ & (ii') queda \\
\hline \multirow{2}{*}{ mythos } & Orfeu & $\begin{array}{c}\text { Viagem } \\
\text { com os } \\
\text { Argonautas }\end{array}$ & $\begin{array}{c}\mathrm{O} \\
\text { casamento }\end{array}$ & $\begin{array}{l}\text { Olhar } \\
\text { para } \\
\text { trás }\end{array}$ & $\begin{array}{c}\text { Subir de } \\
\text { volta do } \\
\text { Hades } \\
\text { para a } \\
\text { superfície }\end{array}$ & $\begin{array}{l}\text { Perde a amada e } \\
\text { é punido com a } \\
\text { morte por } \\
\text { esquartejamento }\end{array}$ \\
\hline & Lúcifer & $\begin{array}{l}\text { Anjo do } \\
\text { cortejo de } \\
\text { Deus }\end{array}$ & $\begin{array}{l}\text { Assemelhar- } \\
\text { se a Deus }\end{array}$ & $\begin{array}{c}\text { A } \\
\text { soberba }\end{array}$ & $\begin{array}{c}\text { Desejar } \\
\text { subir ao } \\
\text { "ponto } \\
\text { mais } \\
\text { elevado } \\
\text { de Zafon" }\end{array}$ & $\begin{array}{l}\text { Jogado ao } \\
\text { abismo por } \\
\text { Deus }\end{array}$ \\
\hline
\end{tabular}

O esquema serve de representação visual da sequência de eventos que caracteriza o tópos do herói caído como um mito, uma narrativa. E é pela narrativa desse mito que, ademais, poderemos compreender Orfeu como esse símbolo do poeta prototípico, que representa em si não apenas o poeta, mas também, pela sua vida, a poesia em si.

Revista Texto Poético | ISSN: 1808-5385 | Vol. 18 (10 sem-2015) - p. 223 


\section{O pecado adâmico e a origem da angústia criativa}

É importante salientar que o mythos apresentado pelo tópos se desenvolve sobre um reconhecimento de um erro. Esse erro, nos dois casos, é origem de uma angústia existencial: no caso de Orfeu, o reconhecimento do erro o fará caminhar sem rumo até ser morto e despedaçado; no caso de Lúcifer, o próprio abismo simboliza a angústia, além da afirmação do rebaixamento do anjo, questionado pelos que o veem sobre seu próprio poder: "Porventura é este homem que fazia tremer a terra inteira, que abalava reinos?". Essa angústia está atrelada, necessariamente, a um questionamento existencial: assim como Orfeu não podia mais viver sem sua musa, Eurídice, o Anjo caído não podia ser o que queria, queria ser mais, o próprio Deus. Suas existências eram dependentes de algo que não possuíam - Eurídice/Deus - e seus erros ligados a um movimento de observação/desejo de um objeto inalcançável, ligado intimamente com a sua própria existência.

Ao lidar com a angústia existencial, o filósofo e teólogo dinamarquês Søren Kierkegaard (1813-1855) compara o sentimento de angústia à vertigem de estar diante do abismo:

A angústia pode ser comparada à vertigem. Quando o olhar imerge num abismo, existe uma vertigem, que nos chega tanto do olhar como do abismo, visto que nos seria impossivel deixar de o encarar. Esta é a angústia: vertigem de liberdade, que surge quando, ao desejar o espirito estabelecer a sintese, a liberdade imerge o olhar no abismo das suas possibilidades e agarra-se à finitude para não soçobrar (KIERKEGAARD apud OLIVIÉRI, 2008, p. 45-46). 
O primeiro ponto importante na análise de Kierkegaard é o reconhecimento da angústia como vertigem. A sensação da vertigem é a experimentação antecipada de uma queda, que parece inevitável diante das circunstâncias, mas não é em si a queda. Ou seja, a angústia se manifesta no limite entre o acontecimento real e a projeção do acontecimento. É o medo que toma conta de Orfeu ao olhar para trás, ao tentar buscar com seus olhos a amada perdida. É a sensação que faz com que Lúcifer olhe para cima, almejando ser mais do que é, e tente rebelar-se contra sua existência.

O segundo ponto é o fato de que a vertigem "chega tanto do olhar como do abismo, visto que nos seria impossível deixar de o encarar". Com isso, Kierkegaard apresenta a dupla natureza dessa queda: a angústia interna, que vem do olhar, é responsabilidade do ato de olhar, mas, ao mesmo tempo, é reflexo da existência de um abismo. O reconhecimento do abismo é impossível de se evitar, pois o abismo - a lacuna, a falta que explica o desejo - existe dentro do próprio eu, sendo a angústia o medo de mergulhar em sua própria essência incompleta.

Por fim, o terceiro ponto a se destacar é que essa angústia é, para Kierkegaard, uma "vertigem de liberdade". É por saber-se livre para escolher que o indivíduo experimenta a angústia, pois no momento em que se vê diante da decisão se abrem ao menos dois caminhos: do acerto e do erro. Essa associação entre angústia e liberdade foi recuperada pelo filósofo existencialista Jean-Paul Sartre:

É na angústia que o homem toma consciência de sua liberdade, ou, se se prefere, a angústia é o modo de ser da liberdade como consciência de ser; é na angústia que a

Revista Texto Poético | ISSN: 1808-5385 | Vol. 18 (10 sem-2015) - p. 225 
liberdade está em seu ser colocando-se a si mesmo em questão. (SARTRE, 2007, p. 72).

Sartre, ao chamar atenção para a distinção entre angústia e medo, corrobora de tal modo com Kierkegaard, afirmando que "a vertigem é a angústia na medida que tenho medo, não de cair no precipício, mas de me jogar nele" (2007, p. 73). É por conta disso que o filósofo francês afirmará que o ser humano está condenado a ser livre, que a liberdade seria de certo modo um fardo que se revela pela própria consciência de liberdade, ou seja, a angústia é consequência inevitável do ato de libertar-se.

A liberdade é ainda um movimento de rebeldia contra a autoridade, representada pelos deuses nos mythos, e a desobediência que leva à queda é a vitória do herói caído contra as restrições impostas por seres mais poderosos que ele. A relação entre o ato poético e o ato de rebeldia é fundamental para a compreensão da poesia, ao menos desde o Romantismo e especialmente para a Modernidade, e tratar do tema de maneira aprofundada seria impossível aqui. O importante é pensar o erro como consequência do ato de rebeldia e, de tal modo, entender a angústia não apenas como o pecado original, mas como motor da criatividade.

A realidade, é que a existência, é possibilidade (sic) e, portanto, quase sempre angústia. Como Kierkegaard afirma, quanto maior a liberdade potencial do indivíduo, tanto maior a possibilidade criativa tem o homem individualmente; desse modo, maior é a sua angústia existencial. Este pensamento o conduziu ao importante conceito da relação do conflito com a angústia. Kierkegaard deu um tratamento original e polêmico ao conflito, criatividade e culpa. Ele supõe que o conflito interno e o sentimento de culpa são sempre uma 
consequência da criatividade. Sendo assim, não devemos classificar o indivíduo de neurótico, mas sim, reconhecer que a angústia existencial tem um papel fundamental nas crises de criatividade, ajudando mesmo a resolvê-las e agraciando um maior desenvolvimento ao eu individual. Destarte cada possibilidade criativa, tratando-se do desenvolvimento individual, implica, pois, certa destruição do passado que possibilita a ruptura de formas nele alicerçadas, sendo possível destruí-las para dar lugar ao novo. (OLIVIÉRI, 2008, p.50).

Há dois pontos a se salientar. Em primeiro lugar, a criatividade como origem de um sentimento de conflito interno, de culpa, que nos impediria de classificar, a priori, o angustiado como um neurótico, visto que essa angústia alimenta sua criatividade. Não haveria, portanto, criação sem esse conflito, e todo criador seria sempre um angustiado. Não vamos nos aprofundar mais nessa relação que pode apontar, talvez, para um reducionismo, mas é importante observar que a relação entre o sofrimento e o processo de criação artístico está expresso em diversas obras literárias ao longo de toda a história da humanidade.

O segundo ponto, o novo, que surge da destruição do passado, conduz justamente à nossa análise da queda vivida pelos heróis angustiados, Lúcifer e Orfeu. Ambos vivem uma situação de confronto com suas realidades, um conflito interno pelo qual abandonam suas existências anteriores e passam por um processo de transformação que culminará em uma nova realidade para ambos. Essa nova realidade é trágica - morte e desmembramento/queda no abismo -, porém, é o espaço aberto para a criação. Como pai dos poetas, podemos pensar no mythos de Orfeu como o da própria origem mítica da poesia e, de tal forma, essa origem está 
intimamente ligada ao mito da queda de Orfeu e, nesse sentido, é impossível dissociá-la da angústia sofrida pelo herói.

Se levarmos em conta a caracterização da angústia do ponto de vista psicopatológico, esse confronto com a realidade que advém da destruição do passado remete a um estado neurótico, posto que o erro em si deriva de - e conduz para - um "excesso". E, como observa Berlinck, há no erro um elemento dissociativo em relação à realidade que, talvez, seja a resposta para a "falha" que conduz à criação. Berlinck traz um interessante ponto para compreender essa suposta neurose:

A angústia, primeira manifestação da neurose, é concebida, inicialmente, como um excesso de excitação que não encontra o caminho da descarga e, mais tarde, como um sinal de ameaça futura. Mas, sendo neurose, a angústia $e ́$, principalmente, repetição, e, por isso, não se refere àquilo que se denomina objetiva realidade. Há, pois, na angústia, um evidente anacronismo, já que se trata de manifestação referida ao passado repetindo-se no presente diante de uma situação que rememora o passado, mas que, além disso, pouco se relaciona com ele. (BERLINCK, 1999, p. 54).

O comentário de Berlinck, nessa passagem, remete à visão que Freud possui sobre o corpo, atribuindo a todos os órgãos uma possibilidade de excitação e, por conseguinte, caracterizando a angústia como um excesso de excitação, que necessitaria de uma descarga. Mas, como se trata de um estado de expectativa, ela culmina sempre numa repetição, pois, poderíamos dizer, o angustiado é aquele que fica na "iminência de".

Como o objeto de Berlinck no texto é a dor, essa será a descarga necessária para sanar a angústia e a neurose - similar à descarga

Revista Texto Poético | ISSN: 1808-5385 | Vol. 18 (10 sem-2015) - p. 228 
sexual. Para ele, a humanidade seria "uma espécie dolorida", e a saúde humana o "desejo de retorno a um estado nirvânico onde dor, depressão e angústia não existem, mas onde o humano também não existe". Dessa forma, posto que a angústia é encarada como inerente à condição humana, a descarga do criador poderia afetar sua própria criação, a sua poiésis. $\mathrm{O}$ ato criador possui a mesma possibilidade de contato com o ato sexual - ambos visam originalmente o surgimento de outro "ser" e derivam, no caso dos heróis caídos, de uma situação de desejo - e, portanto, é possível encarar essa angústia como um "motor" dessa criação, como observa Kierkegaard, o que converge com a visão do angustiado, do caído, como o poeta.

O herói caído vive um conflito com esse passado, e, como traz à baila uma situação mítica, é possível encarar todo ato criador como uma repetição, como um rito que remete e presentifica o passado edênico. Edênico posto que, ao renegar a sua natureza e se entregar ao desejo, os heróis caídos praticam o pecado original, o da desobediência diante da divindade. O pecado de Adão possui, aliás, uma simbologia ideal para fechar o ciclo do herói caído.

Em primeiro lugar, Adão peca por consequência de uma tentação, empreendida pela serpente - e é difícil dissociar, mais uma vez, o animal do demônio/anjo Lúcifer -, que incute nele o desejo (i) que o leva a cometer o erro (ii) de quebrar com as normas estabelecidas e, ao comer do fruto da árvore proibida, ele é punido com a expulsão do paraíso (ii'). A coreografia, com exceção do ato ascensional, é muito similar à dos mythoi analisados.

Ao cometerem o pecado, Adão e sua companheira Eva se reconhecem nus e sentem vergonha. $\mathrm{O}$ reconhecimento de sua nudez pode ser visto como uma alegoria do abandono da inocência e da ignorância do estado edênico e do consequente mergulho no mundo 
do conhecimento, da razão e, por conseguinte, do sofrimento que deriva dessa condição. Adão e Eva vivem a mesma situação de Orfeu e, em nossa análise, de Lúcifer: seres que, diante do reconhecimento e do confronto com sua frágil natureza, são arremessados ao mundo sob sua própria sorte, mas desse mergulho geram o conhecimento. $\mathrm{O}$ ato da desobediência pelo desejo gera, portanto, e ao mesmo tempo, a angústia e o conhecimento, e é impossível dissociar assim a razão da dor existencial. $\mathrm{E}$ a arte seria, nesse sentido, a grande rebeldia contra uma imperiosa ordem estabelecida. Muitos são os autores - poetas, artistas ou teóricos - que se debruçarão sobre essa faceta da obra artística, que reside na própria essência do mythos do artista, do herói caído como um anjo rebelde.

Contudo, se a divindade desobedecida no mythos é Deus/Hades, qual seria a divindade contra qual o Poeta se rebela? Ora, podemos lançar mão de vários exemplos para esse mythos: o poeta maldito contra a moral; o poeta na torre de marfim contra o mundo; o poeta engajado contra o sistema opressor; e até o poeta existencialista contra, talvez, seu próprio eu - ou a percepção que se faz desse eu. Ademais, é o mesmo arquétipo que reside na essência do gauche de Drummond - para citar apenas um exemplo famoso da literatura brasileira -, que se reconhece justamente um "anjo torto". Aliás, o poema de Drummond possui "sete faces", como são sete as cabeças da besta - que poderia ser o próprio Satã - que aparece descrito no livro do Apocalipse segundo São João. E, nesse mesmo poema, encontraremos o eco da desolação angustiada do anjo caído, quando o anjo torto clama a Deus:

Meu Deus, por que me abandonaste
se sabias que eu não era Deus
se sabias que eu era fraco

Revista Texto Poético | ISSN: 1808-5385 | Vol. 18 (1o sem-2015) - p. 230 
Ademais da referência explícita ao clamor de Jesus Cristo, diante de seu destino funesto no Evangelho segundo São Mateus (Mt. 27:46) e ao Salmo 22, que prenunciaria essa situação, podemos enxergar nos versos destacados outro ser abandonado, o próprio anjo torto de sete faces, Lúcifer, que fora punido por Deus justamente por não poder ser ele mesmo Deus e assim, reconhecendo-se fraco, vive a angústia desse abandono. A fragilidade do poeta-anjo se confunde com a do humano-deus, numa aproximação entre Lúcifer e Jesus que encontra lugar no próprio Apocalipse, quando o próprio Cristo se equipara à Estrela da Manhã (KELLY, 2008, p.9).

\section{Conclusão}

Como no caso de Orfeu, o ato criador poético é um ato de olhar para trás, de voltar-se para seu passado, como Kierkegaard afirma:

O poeta é o gênio da recordação. Nada mais pode fazer do que recordar; nada mais senão admirar o que foi cumprido pelo herói. O poeta nada tira de seu próprio fundo, mas guarda ciosamente aquilo que lhe é entregue sob custódia. Segue a escolha do seu coração; encontrado o objeto da sua pesquisa, vai, de porta em porta, recitar os seus versos e discursos para que todos participem da sua admiração pelo herói e dele se orgulhem também. (KIERKEGAARD apud OLIVIÉRI, 2008, p.36).

O abismo do poeta é o abismo de sua existência, mas "nada tira de seu próprio fundo" pois essa existência, ao ser-lhe negado o desejo, é vazia. Ele admira o que foi cumprido pelo herói pois ele é, em si, um ser que não conseguiu cumprir seu feito. Ele canta o herói

Revista Texto Poético | ISSN: 1808-5385 | Vol. 18 (10 sem-2015) - p. 231 
mas, em si, vive um outro herói que em seus versos se apresenta, o herói caído.

E, como vimos, o exercício poético é necessariamente um exercício de observação. Olhar para dentro do abismo - si mesmo , olhar para trás e olhar para cima - ambos símbolos de seu desejo. Esse olhar é revelador, e surge dele a instância criativa que lega ao poeta a responsabilidade quase insustentável de criar. E, se o poeta cria para preencher seu vazio, é possível pensar que o motor de sua arte é a angústia básica do ser, de reconhecer-se vazio e frágil. Acrescente-se a isso a percepção de sua liberdade: ser livre é, ao mesmo tempo, salvação e pena. A liberdade, se o permite criar, rebelar-se contra o criador - a divindade -, o joga ao mundo à sua própria sorte, lhe atribuindo a terrível responsabilidade de arcar com as consequências de seus atos. Talvez aí, equilibrando o indivíduo diante do abismo, a arte surja como uma resposta do imaginário para a perda da relação do humano com a realidade, como observa Oliviéri (2008, p. 85):

Por individuo-artista entendemos que seja aquele indivíduo que exercite seu olhar e proponha uma nova ordem, um novo jogo, um novo objeto para a vasta experiencia que ele pode ter com o mundo. O indivíduo-artista é um construtor de orbes; podemos considerar aqueles indivíduos que se dedicam à criação de sua existência como obra de arte como poetas, ou seja, fazedores de "coisas" que ainda não existem e que "constroem" seu caminho através de sua dor e angústia. "Se uma pessoa é artista, é uma garantia de sanidade. Ela é capaz de suportar seu tormento" (BOURGEOIS, 2000, p. 277).

Ao mesmo tempo em que a angústia dá a real dimensão da existência do humano, o "conhece-te a ti mesmo", como uma 
necessidade para uma existência autêntica, Orfeu e Lúcifer revelamnos que toda poesia é, em si, debruçar-se sobre o ato criador, o que dá a dimensão da existência do poeta como humano, uma existência poética e transcendental. $\mathrm{Ou}$, nas palavras de Kierkegaard:

Que é um poeta? Um ser humano infeliz que encerra em seu coração profundos tormentos, porém seus lábios são formados de tal modo que, quando os suspiros e os gritos fluem por sobre eles, ressoam como uma linda música. Com ele acontece o que ocorria aos infelizes que eram torturados demoradamente, com fogo lento, no boi de Falaris, e cujos gritos não podiam alcançar os ouvidos do tirano para não assustá-lo; a este os gritos soavam como uma doce música. E os homens se reúnem em multidão ao redor do poeta e lhe dizem: Vamos, canta de novo, quer dizer, tomara que novos sofrimentos martirizem tua alma, e Oxalá teus lábios continuem sempre formados como até agora; pois o grito apenas nos assustaria, mas a música, esta sim é deliciosa. E os críticos se chegam e falam: Assim está correto, é assim que deve ser, de acordo com as regras da Estética. Ora, dá para compreender, um crítico de arte é exatamente igual a um poeta, só que não tem os tormentos no coração e nenhuma música nos lábios. Olha, por isso eu prefiro ser um pastor de porcos na Amagerbro e ser compreendido por eles do que ser poeta e ser incompreendido pelos homens. (KIERKEGAARD In ALVARO VALLS, 2004, p. 19).

O Poeta é um incompreendido: aquele que se rebela contra a ordem e faz de sua existência angustiada o motor da criação. Todavia, no plano de uma simbologia tão alegórica, que é o caminho que traçamos ao longo desse texto, talvez a maior rebeldia do Poeta seja contra a sua própria língua: ele rompe com as regras estabelecidas, com a ordem e as formas sintáticas, e as submete ao seu poder. E essa é a ordem que mais se aproxima àquela da

Revista Texto Poético | ISSN: 1808-5385 | Vol. 18 (10 sem-2015) - p. 233 
divindade religiosa pois, em geral, é pela língua que o próprio eu se define, é dela que o poeta constrói o seu devir. A poesia como ato de desobediência que revela, ao mesmo tempo, uma angústia existencial: essa é a natureza da obra do Poeta como herói caído.

\section{Agradecimentos}

Agradeço a André Luiz Machado pela versão em inglês do resumo e à Marina Bariani Trava pela revisão do texto.

\section{Referências}

ANDRADE, C. D. de. Alguma poesia. São Paulo: Companhia das Letras, 2013.

BERLINCK, M. T. A dor. In: (org.). In: Revista Latinoamericana de Psicopatologia Fundamental. São Paulo: Volume 2, Número 3, setembro de 1999, p. 46-58.

DINIZ, F. G. M. A religião, a magia e o canto de Orfeu na Argonáutica de Apolônio de Rodes. Araraquara: Tese de Doutorado/Programa de PósGraduação em Estudos Literários da FCLAr, 2014. Disponível em: http://portal.fclar.unesp.br/posestlit/teses/Fabio_Geronimo_Mota_Di niz_DO.pdf. Acesso em: 10 jan. 2015.

FEKKES, J. Isaiah and Prophetic Traditions in the Book of Revelation. London, New York City: Continuum, 1994.

FERNANDES, R. M. R. Catábase ou descida aos infernos. Alguns exemplos literários. In: Hvmanitas XLV. Coimbra: Universidade de Coimbra, 1993. p. 347-360.

FORSYTH, N. The Old Enemy: Satan and the Combat Myth. Princeton: Princeton University Press, 1989. 
JEROME St. Vulgate Bible. Ed. Bible Foundation and On-Line Book Initiative.

Disponível

em:

http://www.perseus.tufts.edu/hopper/text?doc=urn:cts:greekLit:tlg05 27.tlg001.perseus-lat1:1.1. Acesso em: 12 jun. 2015.

KELLY, H, A. Satã: uma Biografia. Tradução de Renato Rezende. São Paulo: Globo, 2008.

OLIVIÉRI, M. de F. Angústia existencial: o papel fundamental do conceito de angústia no processo de construção da subjetividade humana sob a ótica reflexiva de Sören Aabye Kierkegaard. São Leopoldo: Dissertação de Mestrado / Universidade do Vale do Rio dos Sinos, Programa de Pós-Graduação em Filosofia, 2008. Disponível em: http://biblioteca.asav.org.br/vinculos/tede/angustia\%20existencial.pd f. Acesso em: 10 jan. 2015.

PIRES, A. D. Orfeu sem travessa: leitura de um poema de José Paulo Paes. In: Signótica: Revista do Programa de Pós-Graduação em Letras e Linguística/Faculdade de Letras. Goiânia: Programa de Pós-Graduação em Letras e Linguística / Faculdade de Letras, v. 25, n. 1, jan.jun. 2013, p. 69-80.

SARTRE, J.-P. O Ser e o Nada: Ensaio de Ontologia Fenomenológica. Tradução e notas de Paulo Perdigão. Petrópolis, RJ: Vozes, 2007.

VAILATTI, C. A. O rei da Babilônia e o rei de Tiro: uma análise de Isáas 14:12-15 e Ezequiel 28:11-19. In: Revista Vértices. São Paulo: Programa de Pós-Graduação em Estudos Judaicos e Estudos Árabes / Departamento de Letras Orientais da Faculdade de Filosofia, Letras e Ciências Humanas da Universidade de São Paulo, №. 16, 2014, p. 107-138.

VALLS, A. L. M (organizador, tradutor e apresentador). Do Desespero Silencioso ao elogio do Amor Desinteressado. Aforismos, Novelas e Discursos de Sören Kierkegaard.. Porto Alegre: Escritos, 2004. 
